\title{
FUNCTIONAL CAPACITY IN THE \\ OLDEST OLD: CROSS-SECTIONAL ANALYSIS BASED ON A DECISION MODEL
}

\author{
Capacidade funcional de idosos longevos: \\ análise transversal baseada em um modelo de decisão
}

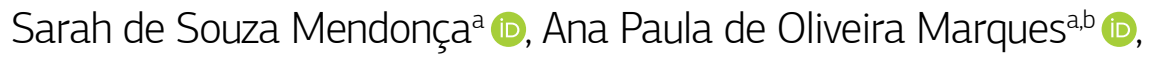 \\ Marília Gabrielle Santos Nunes ${ }^{\mathrm{a}}\left(\mathbb{D}\right.$, Edson Rios D’Angelo ${ }^{\mathrm{b}}$ (D), Márcia Carrera Campos Leal ${ }^{\mathrm{a}, \mathrm{b}}$ (1)
}

INTRODUCTION: The oldest old adults, aged 80 years and above, is the fastest growing age group in the world. In this section of the population, functional disability (FD) is more prevalent compared to other age groups. OBJECTIVE: To characterize functional capacity and analyze potential associations in the oldest old from a Brazilian capital city, based on a decision model. METHODS: Cross-sectional study of 100 non-institutionalized oldest old participants assisted at the Family Health Strategy of Recife, in the Brazilian northeastern state of Pernambuco, selected by probabilistic sample. Sociodemographic, economic, and clinical data were collected by means of home interviews, anthropometric measurements, and medical records. For bivariate analysis, Pearson's chi-square test was used, establishing significance at $p<0.05$. For the multivariate analysis, a decision tree was built from the Exhaustive CHAID algorithm. RESULTS: The prevalence of FD in the sample corresponded to $67.0 \%$. In the bivariate analysis, the following data contributed to this outcome: income $(p=0.032)$, social security status $(p<0.01)$, nutritional status ( $p=0.010)$, neurological diseases $(p<0.01)$, neoplasms $(p<0.01)$, self-perceived health $(p=0.025)$ and social support network $(p=0.032)$, remaining in the multivariate analysis: income $(p=0.003)$, social support network $(p=0.032)$, and nutritional status $(p=0.040)$. The decision tree allowed the identification of the variables most strongly associated with the outcome, being able to adequately predict moderate dependence, with $72.1 \%$ assertiveness. CONCLUSION: The decision model proved to be a timely tool in deducing the most relevant determinants of FD. Its use potentially contributes to increase the accuracy of the diagnosis and to identify populations at risk.

KEYWORDS: the oldest old; activities of daily living; geriatric assessment; primary health care; decisions trees.

aGraduate Program in Collective Health, Universidade Federal de Pernambuco - Recife (PE), Brazil.

${ }^{\mathrm{b}}$ Graduate Program in Gerontology, Universidade Federal de Pernambuco - Recife (PE), Brazil.

Correspondence data

Sarah de Souza Mendonça - Hospital das Clínicas - Avenida Professor Moraes Rego, s/n, Bloco E, 40 andar - Cidade Universitária - CEP: $50.670-901$ Recife (PE), Brazil. E-mail: ssmendonca@gmail.com

Received on: 07/23/2019. Accepted on: 01/08/2020

DOI: 10.5327/Z2447-212320202000049

(C) 2020 Sociedade Brasileira de Geriatria e Gerontologia 
INTRODUÇÃO: Idosos com 80 anos ou mais, ou longevos, são o subgrupo etário que mais cresce no mundo. Nesse segmento, a incapacidade funcional (IF) é mais prevalente que em outras faixas etárias. OBJETIVO: Caracterizar a capacidade funcional e analisar potenciais associações em idosos longevos de uma capital brasileira, com base em um modelo de decisão. MÉTODO: Estudo transversal com 100 idosos longevos, não institucionalizados, assistidos pela Estratégia Saúde da Família do Recife (PE), selecionados por amostra probabilística. Foram avaliados dados sociodemográficos, econômicos e clínicos coletados por meio de entrevistas domiciliares, aferição de medidas antropométricas e buscas nos prontuários. Para análise bivariada, foi empregado o teste $\chi^{2}$ de Pearson, considerando o nível de significância $p<0,05$, e para a multivariada foi construída uma árvore de decisão com base em um algoritmo Exhaustive CHAID. RESULTADOS: A prevalência de IF na amostra correspondeu a 67,0\%. Na análise bivariada, contribuíram para esse desfecho: renda $(p=0,032)$, situação previdenciária $(p<0,01)$, situação nutricional $(p=0,010)$, doenças neurológicas $(p<0,01)$, neoplasias $(p<0,01)$, saúde autopercebida $(p=0,025)$ e rede de apoio social $(p=0,032)$, permanecendo na análise multivariada: renda $(p=0,003)$, rede de apoio social $(p=0,032)$ e situação nutricional $(p=0,040)$. A árvore de decisão possibilitou a identificação das variáveis mais associadas ao desfecho, sendo capaz de prever adequadamente a dependência moderada, com assertividade de 72,1\%. CONCLUSÃO: O modelo de decisão mostrou-se uma ferramenta oportuna na dedução dos determinantes mais relevantes da IF. Seu uso potencialmente contribui para ampliar a precisão diagnóstica e identificação de populações de risco.

PALAVRAS-CHAVE: idoso de 80 anos ou mais; atividades cotidianas; avaliação geriátrica; atenção primária à saúde; árvores de decisões.

\section{INTRODUCTION}

With the ageing of the population and increasing global life expectancy, the segment of the oldest old, i.e., individuals aged 80 and over, has become the fastest growing age subgroup in the world. This fact, however, brings concern with the increased prevalence of frailty and functional dependence, in addition to the increase in health care costs. ${ }^{1}$

The term functional capacity refers to the maintenance of the physical and mental abilities necessary for an independent and autonomous life, and is directly related to the ability of performing activities of daily living (ADLs), fundamental for the assurance of self-preservation and survival of the individual. The reduction of functional capacity predisposes the older population to dependence, falls, and institutionalization, representing a factor for hospitalization and death of this population. ${ }^{2}$

The evaluation of functional capacity emerges as a paradigm in the health of the aged person due to the viability of keeping these individuals active, independent and autonomous for a longer time and actively participating in society, even in the presence of diseases. ${ }^{3}$

Recife is the sixth capital city with the highest proportion of older people in the country, ${ }^{4}$ prevailing those who depend on the assistance provided by the Brazilian Unified Health System (SUS). ${ }^{5}$ Given this reality, this research aimed to evaluate the functional capacity of the oldest old assisted by the Family Health Strategy of Recife, an age segment still under investigation, and its association with socio-demographic, economic, and clinical variables, based on the decision tree model, a statistical model based on successive $\chi^{2}$ association tests. Based on a list of possible predictors, this model traces a path from the most influential to the least influential association, reducing a complex decision to a finite number of simple elements in relation to the dependent variable, justifying the choice of the method.

\section{METHODS}

This was a quantitative cross-sectional study with non-institutionalized oldest old adults of both sexes, assisted by Family Health teams from the micro-region 4.2 of the city of Recife. The oldest old population was identified by surveying all medical records of patients within this age group in the health units of the territory, corresponding to 485 individuals aged 80 years and above.

The present investigation represents an excerpt of the study 'Successful aging in the oldest old and associated factors' (Envelhecimento bem-sucedido em idosos longevos efatores associados), approved by the Research Ethics Committee of Universidade Federal de Pernambuco (under approval number CAEE 34900514.0.0000.5208), whose sample was calculated considering the population estimate of older adults living in the 4.2 micro-region of Recife. The dependent variable was equal to 31.3196 , margin of error of 3.7644 and 95\% confidence level.

Thus, 172 individuals were selected by probabilistic sample, and those with cognitive impairment that prevented them from responding to the instruments were excluded.The participants themselves had to answer questions related to self-perception of health, social support network, and depressive 
symptoms, quantitative that corresponding to the 72 participants. At the end, a total of 100 older people composed the sample. The subjects were only evaluated after they were aware of the objectives of the study and registered their consent, by signature or fingerprint, in the Informed Consent Form.

After this stage, home interviews were conducted between April and August 2015, using a semi-structured questionnaire to record the information, organized into thematic blocks: sociodemographic, economic, and clinical data. Functional capacity was assessed using the Barthel Index ${ }^{6}$ and the cutoff points adopted in this study were those proposed by Azeredo and Matos. ${ }^{7}$ For analysis purposes, the functionality variable was previously aggregated into 3 categories: severe dependency ( 0 to 60 points), moderate dependence (61 to 99 points), and independence (100 points).

The cognitive capacity was assessed using the Mini Mental State Examination (MMSE), based on the standard deviation below the education means for the MMSE, according to the schooling cutoff points proposed by Bertolucci et al. ${ }^{8}$ To identify the support from family and friends received and perceived by this population, the Lubben Social Networking Brief Scale ${ }^{9}$ was used, which evaluates the social support network using 2 domains: family and friends, in which the score $\geq 12$ points represents a good social support network, while values below 12 characterize an insufficient support network. In screening for depressive symptoms, the chosen resource corresponded to the 15 -item Geriatric Depression Scale (Geriatric Depressive Symptoms - GDS-15) ${ }^{10}$ whose scores below 5 represents absence of depression, between 5 and 10, minor depression, and above 10, major depression. As for self-perceived health, this was categorized as positive (excellent, very good and good) and negative (regular and bad).

The presence of nutritional risk was determined according to the Mini Nutritional Assessment. ${ }^{11}$ To calculate body mass index (weight/height ${ }^{2}$ ), weight was obtained using a portable G-Teck ${ }^{\circledR}$ digital scale Glass 8 model, with a maximum capacity of $150 \mathrm{~kg}$ and a graduation of $100 \mathrm{~g}$. Height was estimated using the measurement of knee height with the aid of a $\mathrm{Carci}^{\circledR}$ child stadiometer $1.000 \mathrm{~mm}$ long, using the equations proposed by Chumlea et al. ${ }^{12}$

The SPSS software version 19.0 was used for data tabulation and analysis. The association of independent variables and functional capacity was evaluated by means of bivariate analysis using Pearson's $\chi^{2}$ test, with significance established at $5 \%$. In the multivariate analysis, a decision tree was generated using the CHAID exhaustive algorithm.

According to Rokach and Maimon, ${ }^{13}$ decision trees are hierarchical structures that, using a database, repeatedly divide the base into subsets, providing each time a partial result that will feed the next step of the process, making the tree less complex and more understandable. The algorithm does not accept continuous variables as predictors and therefore all those used in this study were categorized.

At the top of the structure lies the root node, with the internal nodes below. These represent decision nodes and each contains a test on an independent variable whose outcomes form the branches of the tree. The nodes at the end of the tree represent predictive values for the dependent variable or probability distributions of those values. ${ }^{13}$

\section{RESULTS}

The sample of the present study corresponded to 100 ageing adults, with a mean age of 85.5 years, ranging from 80 to 100 years $( \pm 4.39)$, of which $77(77.0 \%)$ were female. The most prevalent sociodemographic variables were brown race/color (42.0\%), absence of a spouse or partner (78.0\%), 1 to 4 years of schooling (46.0\%), and individual monthly income from 1 to 2 minimum wages (76.0\%), from retirement pays in $73.0 \%$ of the cases (Table 1). As for clinical characteristics, $28.0 \%$ of the sample presented some degree of cognitive impairment and $44.0 \%$ of the oldest old were at risk of malnutrition. In relation to the diagnosis of chronic conditions registered in the medical records, hypertension was the most prevalent (77.0\%), followed by depressive symptoms (36.0\%) (Table 2). Diabetes was observed in approximately $34 \%(n=34)$ of participants, $62 \%(n=62)$ of respondents classified their health negatively, and $63 \%(n=63)$ mentioned having an insufficient social support network (Table 2).

Regarding functional capacity, based on the Barthel Index, $7.0 \%$ of the older adults were identified as severely dependent and $61.0 \%$ as moderately dependent, while $32.0 \%$ of participants were independent (Figure 1).

In the bivariate analysis (Tables 3 and 4), functional capacity showed a statistically significant association with income $(p=0.032)$, social security status $(p=0.010)$, nutritional status $(\mathrm{p}<0.001)$, presence of neurological diseases $(\mathrm{p}<0.01)$ and neoplasms $(\mathrm{p}<0.01)$, in addition to self-perceived health $(\mathrm{p}=0.025)$ and social support network $(\mathrm{p}=0.032)$.

Figure 1 shows the results obtained from multivariate analysis by building a decision tree to test the association between functional capacity and independent variables. The factors that together helped to best explain the dependent variable were social support network, income, and nutritional status.

The root node, or zero node, corresponds to the functional capacity aggregated at functional levels, showing a high prevalence $(67.0 \%)$ of reduced functional capacity (severe dependence and moderate dependence) in the population 
studied. According to the model, the social support network $(p=0.032)$ was the factor that most influenced the presence of functional dependence, with a prevalence of $88.5 \%$ of older adults with unsatisfactory social support (node 1 ) and $60.9 \%$, with satisfactory support network (node 2).

Among the oldest old with a satisfactory support network, income was significantly associated $(p=0.003)$ with reduced functional capacity, which in turn was more prevalent $(71.5 \%)$ in those with higher income (node 3). Among individuals with lower income (less than 2 minimum wages) (node 4),

Table 1 Characterization of the sample of oldest old adults assisted by the Family Health Strategy in Recife, according to sociodemographic and economic variables.

\begin{tabular}{|c|c|c|}
\hline Variables & $\mathbf{N}$ & $\%$ \\
\hline \multicolumn{3}{|l|}{ Age range (years) } \\
\hline 80 to 84 & 54 & 54.0 \\
\hline 85 to 90 & 41 & 41.0 \\
\hline Above 90 & 5 & 5.0 \\
\hline \multicolumn{3}{|l|}{ Sex } \\
\hline Male & 23 & 23.0 \\
\hline Female & 77 & 77.0 \\
\hline \multicolumn{3}{|l|}{ Conjugal situation } \\
\hline Without a spouse or partner & 78 & 78.0 \\
\hline With a spouse or partner & 22 & 22.0 \\
\hline \multicolumn{3}{|l|}{ Education } \\
\hline Illiterate & 30 & 30.0 \\
\hline $1-4$ years & 46 & 46.0 \\
\hline Above 4 years & 24 & 24.0 \\
\hline \multicolumn{3}{|l|}{ Income* } \\
\hline Up to 1 minimum wage & 15 & 15.0 \\
\hline More than 1 to 2 minimum wages & 76 & 76.0 \\
\hline More than 2 to 4 minimum wages & 7 & 7.0 \\
\hline Above 4 minimum wages & 2 & 2.0 \\
\hline \multicolumn{3}{|l|}{ Race } \\
\hline White & 34 & 34.0 \\
\hline Black & 20 & 20.0 \\
\hline Yellow & 4 & 4.0 \\
\hline Brown & 42 & 42.0 \\
\hline \multicolumn{3}{|l|}{ Social security status } \\
\hline Retired & 73 & 73.0 \\
\hline Retired and pensioner & 3 & 3.0 \\
\hline Pensioner & 24 & 24.0 \\
\hline
\end{tabular}

*Salary in force in $2015(\mathrm{R} \$ 788)$. the nutritional situation was responsible for the reduction in functional capacity $(p=0.04)$. In participants with nutritional risk (node 5), 72\% presented functional disability, while among malnourished individuals (node 6), 85.7\% were functionally dependent.

The model shows a level of assertiveness of $66.0 \%$ for the decision tree, however, considering the 3 levels of the response variable, there is $42.9 \%$ assertiveness for severe dependence, $72.1 \%$ for moderate dependence, and $59.4 \%$

Table 2 Characterization of the sample of oldest old adults assisted by the Family Health Strategy of Recife, according to clinical variables.

\begin{tabular}{|l|l|l}
\hline Variables & N & $\%$ \\
\hline
\end{tabular}

Cognitive impairment

\begin{tabular}{l|c|c} 
Present & 28 & 28.0 \\
\hline Nutritional status & 47 & 47.0 \\
\hline Normal & 44 & 44.0 \\
\hline Nutritional risk & 9 & 9.0 \\
\hline Malnutrition
\end{tabular}

\begin{tabular}{l|l|l}
\hline Hypertension & \multicolumn{2}{l}{} \\
\hline Present & 77 & 77.0 \\
\hline Diabetes mellitus
\end{tabular}

Diabetes mellitus
\begin{tabular}{l|l|l}
\hline Present & 34 & 34.0 \\
\hline Cardiovascular diseases
\end{tabular}

\begin{tabular}{c|c|c}
\hline Present & 27 & 27.0 \\
\hline Osteoporosis & 23 & 23.0
\end{tabular}

\begin{tabular}{l|c|c}
\hline Present & 23 & 23.0 \\
\hline Osteoarthrosis & 22 & 22.0 \\
\hline Present & 5 & 5.0 \\
\hline Neurological diseases & \multicolumn{1}{|l}{} \\
\hline Present & 5
\end{tabular}

Respiratory diseases

\begin{tabular}{|c|c|c|}
\hline Present & 9 & 9.0 \\
\hline \multicolumn{3}{|l|}{ Neoplasms } \\
\hline Present & 3 & 3.0 \\
\hline \multicolumn{3}{|l|}{ Depression } \\
\hline Present & 36 & 36.0 \\
\hline \multicolumn{3}{|l|}{ Self-perceived health } \\
\hline Negative & 62 & 62.0 \\
\hline Positive & 38 & 38.0 \\
\hline \multicolumn{3}{|l|}{ Social support network } \\
\hline Good social network & 37 & 37.0 \\
\hline Insufficient social network & 63 & 63.0 \\
\hline
\end{tabular}


for independence. In summary, with the available variables associated with functional capacity, the decision tree was able to adequately predict moderate dependency.

\section{DISCUSSION}

The results of this study identified a high prevalence of functional dependence for ADLs in the sample (67.0\%), similar to that observed in the study by Brito et al., ${ }^{14}$ whose scenario and population were similar to this study, as well as its strong association with the social support network, income and nutritional status as factors that predispose the oldest old to develop functional deficit and dependence.

In relation to the socio-demographic and economic variables, there is a similarity in the profile of the participants interviewed with the population of other studies, which were also developed within the Family Health Strategy. ${ }^{15,16}$ The predominance of older women characterizes the phenomenon of feminization of ageing, attributed to lower female mortality, because they seek more health services and are less exposed to accidents, violence and risk behaviors in relation to men. ${ }^{17} \mathrm{It}$ is noteworthy that schooling and income are inversely proportional to functional capacity; therefore, the lower the educational and financial levels, the greater the chances of developing dependency for ADLs. ${ }^{18}$ In this study, having income below 2 minimum wages was statistically associated with reduced functional capacity in the bivariate analysis. For schooling, however, this association was not observed.

The social security situation was also statistically associated with reduced functional capacity in the bivariate analysis.

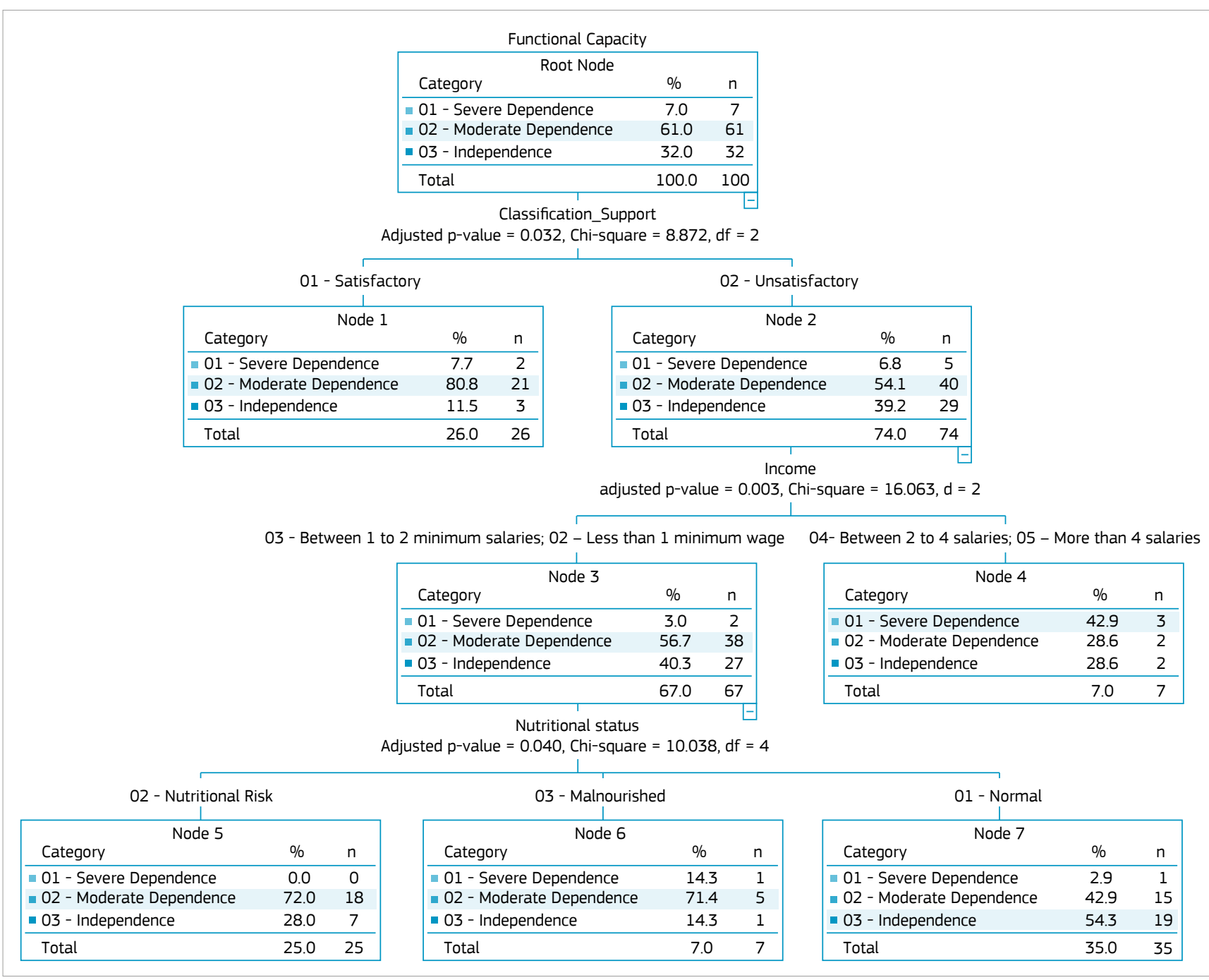

Figure 1 Multivariate analysis of factors associated with the functional capacity of the oldest old assisted at the Family Health Strategy in Recife, using the decision tree, with the exhaustive CHAID algorithm. 
Andrade et al., ${ }^{19}$ in a study on the factors associated with receiving pensions by older adults, pointed out that age, as expected, is the factor that is most strongly associated with receiving retirement benefits and pension, besides other conditions, such as home arrangement (living alone or with someone), support received at home, medical diagnosis of chronic diseases, and having functional limitations. ${ }^{19}$

Chronic diseases are frequent in the older population and interfere greatly in the functional capacity of this group, as observed by Nascimento et al. ${ }^{20}$ when they found a statistically significant association in hypertension, diabetes and functional capacity. In the present study, along with depression, these were the most frequent pathologies, but the presence of neurological diseases and neoplasms were the only morbid conditions that presented association with the dependent variable in the bivariate analysis, corroborating the research of Ribeiro et al. ${ }^{21}$ and Carbonel1 ${ }^{22}$, respectively.

Table 3 Bivariate analysis of factors associated with the functional capacity of the oldest old assisted at the Family Health Strategy in Recife, concerning sociodemographic variables*.

\begin{tabular}{|c|c|c|c|c|c|c|c|c|c|}
\hline \multirow{2}{*}{ Variables } & \multicolumn{2}{|c|}{$\begin{array}{c}\text { Severe } \\
\text { Dependence }\end{array}$} & \multicolumn{2}{|c|}{$\begin{array}{c}\text { Moderate } \\
\text { Independence }\end{array}$} & \multicolumn{2}{|c|}{ Independence } & \multicolumn{2}{|c|}{ Total } & \multirow[t]{2}{*}{ IC95\% } \\
\hline & $\mathbf{N}$ & $\%$ & $\mathbf{N}$ & $\%$ & $\mathbf{N}$ & $\%$ & $\mathbf{N}$ & $\%$ & \\
\hline
\end{tabular}

Age range (years)

\begin{tabular}{|c|c|c|c|c|c|c|c|c|c|c|}
\hline 80 to 84 & 5 & 9.3 & 32 & 59.3 & 17 & 31.5 & 54 & 100 & $(13.84 ; 22.16)$ & \multirow{3}{*}{$0.57 \varepsilon$} \\
\hline 85 to 90 & 2 & 4.9 & 27 & 65.9 & 12 & 29.3 & 41 & 100 & $(9.65 ; 17.68)$ & \\
\hline Above 90 & 0 & 0.0 & 2 & 40.0 & 3 & 60.0 & 5 & 100 & $(0.27 ; 3.07)$ & \\
\hline \multicolumn{11}{|l|}{ Sex } \\
\hline Men & 3 & 13.0 & 11 & 47.8 & 9 & 39.1 & 23 & 100 & (5.36; 9.98) & \multirow{2}{*}{0.237} \\
\hline Women & 4 & 5.2 & 50 & 64.9 & 23 & 29.9 & 77 & 100 & $(20.23 ; 31.11)$ & \\
\hline \multicolumn{11}{|l|}{ Conjugal status } \\
\hline No partner & 5 & 6.4 & 49 & 62.8 & 24 & 30.8 & 78 & 100 & $(20.68 ; 31.32)$ & \multirow{2}{*}{0.906} \\
\hline With partner & 2 & 9.1 & 12 & 54.5 & 8 & 36.4 & 22 & 100 & (4.79; 9.87) & \\
\hline \multicolumn{11}{|l|}{ Education } \\
\hline Illiterate & 1 & 3.3 & 19 & 63.3 & 10 & 33.3 & 30 & 100 & $(6.61 ; 13.39)$ & \multirow{3}{*}{0.354} \\
\hline 1 to 4 years & 2 & 4.3 & 31 & 67.4 & 13 & 28.3 & 46 & 100 & $(11 ; 19.66)$ & \\
\hline Above 4 years & 4 & 16.7 & 11 & 45.8 & 9 & 37.5 & 24 & 100 & $(5.85 ; 10.15)$ & \\
\hline \multicolumn{11}{|l|}{ Income } \\
\hline Up to 1 minimum wage & 0 & 0.0 & 8 & 53.3 & 7 & 46.7 & 15 & 100 & $(2.64 ; 7.36)$ & \multirow{4}{*}{0.032} \\
\hline $1-2$ salaries & 4 & 5.3 & 49 & 64.5 & 23 & 30.3 & 76 & 100 & $(19.95 ; 30.71)$ & \\
\hline 2- 4 salaries & 2 & 28.6 & 3 & 42.9 & 2 & 28.6 & 7 & 100 & $(1.47 ; 3.19)$ & \\
\hline More than 4 salaries & 1 & 50.0 & 1 & 50.0 & 0 & 0 & 2 & 100 & $(-0.19 ; 1.53)$ & \\
\hline \multicolumn{11}{|l|}{ Race/Color } \\
\hline White & 2 & 5.9 & 22 & 64.7 & 10 & 29.4 & 34 & 100 & $(7.74 ; 14.92)$ & \multirow{4}{*}{0.811} \\
\hline Black & 2 & 10.0 & 12 & 60.0 & 6 & 30.0 & 20 & 100 & $(4.13 ; 9.21)$ & \\
\hline Yellow & 1 & 25.0 & 2 & 50.0 & 1 & 25.0 & 4 & 100 & $(0.47 ; 2.19)$ & \\
\hline Brown & 2 & 4.8 & 25 & 59.5 & 15 & 35.7 & 42 & 100 & $(10.16 ; 17.84)$ & \\
\hline \multicolumn{11}{|l|}{ Pension status } \\
\hline Retired & 5 & 6.8 & 45 & 61.6 & 23 & 31.5 & 73 & 100 & $(19.27 ; 29.4)$ & \multirow{3}{*}{$<0.01$} \\
\hline Retired and pensioner & 2 & 66.7 & 1 & 33.3 & 0 & 0 & 3 & 100 & $(-0.13 ; 2.13)$ & \\
\hline Pensioner & 0 & 0.0 & 15 & 62.5 & 9 & 37.5 & 24 & 100 & $(4.89 ; 11.11)$ & \\
\hline
\end{tabular}

* We used the $\chi^{2}$ test, establishing significance at $p<0.05$ 
Table 4 Bivariate analysis of factors associated with the functional capacity of the oldest old assisted at the Family Health Strategy in Recife, concerning clinical variables*.

\begin{tabular}{|c|c|c|c|c|c|c|c|c|c|c|}
\hline \multirow{3}{*}{ Clinical Conditions } & \multicolumn{10}{|c|}{ Functional capacity } \\
\hline & \multicolumn{2}{|c|}{$\begin{array}{c}\text { Severe } \\
\text { Dependence }\end{array}$} & \multicolumn{2}{|c|}{$\begin{array}{c}\text { Moderate } \\
\text { Dependence }\end{array}$} & \multicolumn{2}{|c|}{ Independence } & \multicolumn{2}{|c|}{ Total } & \multirow{2}{*}{ IC95\% } & \multirow{2}{*}{$\mathbf{p}$} \\
\hline & $\mathbf{N}$ & $\%$ & $\mathbf{N}$ & $\%$ & $\mathbf{N}$ & $\%$ & $\mathbf{N}$ & $\%$ & & \\
\hline \multicolumn{11}{|l|}{ Cognitive Impairment } \\
\hline No & 2 & 7.1 & 14 & 50.0 & 12 & 42.9 & 28 & 100 & $(6.46 ; 12.2)$ & \multirow{2}{*}{0.332} \\
\hline Yes & 5 & 6.9 & 47 & 65.3 & 20 & 27.8 & 72 & 100 & $(18.78 ; 29.22)$ & \\
\hline \multicolumn{11}{|l|}{ Nutritional status } \\
\hline Normal & 1 & 2.1 & 23 & 48.9 & 23 & 48.9 & 47 & 100 & $(11.63 ; 19.7)$ & \multirow{3}{*}{0.010} \\
\hline Nutritional Risk & 5 & 11.4 & 32 & 72.7 & 7 & 15.9 & 44 & 100 & $(10.28 ; 19.06)$ & \\
\hline Malnourished & 1 & 11.1 & 6 & 66.7 & 2 & 22.2 & 9 & 100 & $(1.16 ; 4.84)$ & \\
\hline \multicolumn{11}{|l|}{ Hypertension } \\
\hline No & 2 & 8.7 & 14 & 60.9 & 7 & 30.4 & 23 & 100 & $(4.89 ; 10.44)$ & \multirow{2}{*}{0.930} \\
\hline Yes & 5 & 6.5 & 47 & 61.0 & 25 & 32.5 & 77 & 100 & $(20.48 ; 30.85)$ & \\
\hline \multicolumn{11}{|l|}{ Diabetes } \\
\hline No & 4 & 6.1 & 38 & 57.6 & 24 & 36.4 & 66 & 100 & $(17.32 ; 26.68)$ & \multirow{2}{*}{0.412} \\
\hline Yes & 3 & 8.8 & 23 & 67.6 & 8 & 23.5 & 34 & 100 & $(7.68 ; 14.98)$ & \\
\hline \multicolumn{11}{|c|}{ Cardiovascular Disease } \\
\hline No & 3 & 4.1 & 45 & 61.6 & 25 & 34.2 & 73 & 100 & $(19.15 ; 29.52)$ & \multirow{2}{*}{0.159} \\
\hline Yes & 4 & 14.8 & 16 & 59.3 & 7 & 25.9 & 27 & 100 & $(6.17 ; 11.83)$ & \\
\hline \multicolumn{11}{|l|}{ Osteoporosis } \\
\hline No & 5 & 6.5 & 45 & 58.4 & 27 & 35.1 & 77 & 100 & $(20.6 ; 30.73)$ & \multirow{2}{*}{0.481} \\
\hline Yes & 2 & 8.7 & 16 & 69.6 & 5 & 21.7 & 23 & 100 & $(4.59 ; 10.74)$ & \\
\hline \multicolumn{11}{|l|}{ Osteoarthrosis } \\
\hline No & 5 & 6.4 & 48 & 61.5 & 25 & 32.1 & 78 & 100 & $(20.75 ; 31.25)$ & \multirow{2}{*}{0.908} \\
\hline Yes & 2 & 9.1 & 13 & 59.1 & 7 & 31.8 & 22 & 100 & (4.68; 9.99) & \\
\hline Neurological diseas & & & & & & & & & & \\
\hline No & 4 & 4.2 & 60 & 63.2 & 31 & 32.6 & 95 & 100 & $(25.68 ; 37.66)$ & \\
\hline Yes & 3 & 60.0 & 1 & 20.0 & 1 & 20.0 & 5 & 100 & $(0.45 ; 2.88)$ & -0.01 \\
\hline Respiratory tract dis & & & & & & & & & & \\
\hline No & 6 & 6.6 & 55 & 60.4 & 30 & 33.0 & 91 & 100 & $(24.73 ; 35.93)$ & 0506 \\
\hline Yes & 1 & 11.1 & 6 & 66.7 & 2 & 22.2 & 9 & 100 & $(1.16 ; 4.84)$ & 0 \\
\hline Neoplasm & & & & & & & & & & \\
\hline No & 5 & 5.2 & 60 & 61.9 & 32 & 33.0 & 97 & 100 & $(26.4 ; 38.27)$ & $<0 \cap 1$ \\
\hline Yes & 2 & 66.7 & 1 & 33.3 & 0 & 0.0 & 3 & 100 & $(-0.13 ; 2.13)$ & -0.01 \\
\hline Depression & & & & & & & & & & \\
\hline No & 4 & 6.3 & 35 & 54.7 & 25 & 39.1 & 64 & 100 & $(16.83 ; 25.83)$ & 0120 \\
\hline Yes & 3 & 8.3 & 26 & 72.2 & 7 & 19.4 & 36 & 100 & $(8.03 ; 15.97)$ & 0.150 \\
\hline Self-perceived heal & & & & & & & & & & \\
\hline Negative & 6 & 9.7 & 42 & 67.7 & 14 & 22.6 & 62 & 100 & $(15.75 ; 25.59)$ & ברחת \\
\hline Positive & 1 & 2.6 & 19 & 50.0 & 18 & 47.4 & 38 & 100 & $(9.07 ; 16.27)$ & $0.0<3$ \\
\hline Social Support Netu & & & & & & & & & & \\
\hline Insufficient & 2 & 7.7 & 21 & 80.8 & 3 & 11.5 & 26 & 100 & $(4.97 ; 12.37)$ & \\
\hline Good & 5 & 6.8 & 40 & 54.1 & 29 & 39.2 & 74 & 100 & (19.88; 29.45) & 0.032 \\
\hline
\end{tabular}

*We used the $\chi^{2}$ test, establishing significance at $p<0.05$. 
In this study, $53.0 \%$ of the interviewees $(n=53)$ presented nutritional risk, with positive association with reduced functional capacity in bivariate analysis. The relationship between nutritional risk and disability is bidirectional, since dependence interferes with the nutritional situation by compromising the ability to feed, as well as unfavorable nutritional conditions lead to functional deficit. ${ }^{23}$

The social support network can be defined as the personal, formal and informal interactions through which information, emotional, instrumental and material support are received and social interaction is positive. These social relationships tend to diminish with age, with the loss of social roles, retirement, widowhood and death of friends and family, with damage to self-esteem and propensity to helplessness. ${ }^{24}$ In this survey, most older people referred to an unsatisfactory social support network (62.0\%), whose deleterious effect on functional capacity was proven by a previous study with older adults, which also added that the quality of the social support network is more important than its size. ${ }^{25}$

Boulos et al. ${ }^{26}$ state that older people living alone and with an insufficient social support network, present a 1.2fold higher risk of developing malnutrition. The authors also observed that living alone is associated with poor nutritional status, regardless of the level of depressive symptoms on the Geriatric Depression Scale, meaning that both can act independently from each other in nutritional terms, proving the relationship between social support network and nutritional status.

In this research, prevailed the older adults with negative perception of their health with a positive association for FD in the bivariate analysis. This indicator reproduces the subjective image that individuals themselves have about their physical, cognitive, and emotional aspects and it has been described in the literature as a reliable parameter of FD and mortality in ageing populations. Josefsson et al. ${ }^{27}$ suggest that as age progresses, the possibility of classifying one's own health in a negative way increases.

It was observed in the multivariate analysis that the individuals with unsatisfactory social support network were those with the highest frequency of functional dependence, as expected, due to the fact that they could not count on the support of third parties for their daily needs and tasks. However, unlike most studies, it was in older adults with higher incomes (more than 2 minimum wages) that the highest number of participants with functional dependence was found.

It is known that in Brazil a significant part of older citizens are responsible, or mostly responsible, for the subsistence of homes. ${ }^{28}$ The access to pensions and social security benefits has provided some financial stability to the older adult, making them the head of the household. Due to precarious employment relationships in recent decades, it is increasingly common for adults to remain or return to live with their aged parents, being financially dependent on them. ${ }^{29}$

In these often multigenerational homes, the commitment of most of the income to support and maintain the household and those under its responsibility in some way can make it difficult to access different health services, medications and other factors that contribute to successful aging. This may help explain the higher prevalence of functional dependents in those with higher income. Nutritional risk and malnutrition were identified in individuals with incomes below 2 minimum wages. Lower incomes and educational levels generally induce the choice for cheaper, palatable, and lower nutritional value foods. ${ }^{30}$

In view of the above, we emphasize the importance of including a multidimensional evaluation of older adults in a systematic way in the routine of the Family Health Strategy teams, as it enables the early identification of factors associated with functional disability, as recommended by health policies for older adults.

The present research has as limitations the fact that the instrumental activities of daily living have not been evaluated, considering that hierarchically these are the tasks that suffer the first declines, since they require greater physical and cognitive integrity. ${ }^{30}$ Moreover, the study design itself does not allow inferring a causal relationship between the dependent and the independent variable, as it is only possible to suggest an association between them. The findings presented refer to the casuistry assisted in primary health care, not allowing extrapolation of results to the general population.

\section{CONCLUSION}

Knowledge of the factors involved in functional dependence enables a better understanding of this condition and subsidizes the planning of actions that stimulate healthy and active aging, as recommended by the National Health Policy for the Older Adult. In this study, the decision model proved to be a timely tool in deducing the most relevant determinants of FD in this sample of oldest old adults. Its use potentially contributes to increase the diagnostic accuracy and identification of risk populations, guiding health professionals and managers in clinical decision making.

\section{CONFLICT OF INTERESTS}

The authors declare that there are no conflicts of interest in this study. 


\section{REFERENCES}

1. Centro Internacional de Longevidade Brasil. Envelhecimento ativo: um marco político em resposta à revolução da longevidade. Seção I: A revolução da Longevidade. Rio de Janeiro: ILC-Brasil; 2015.

2. Santos GLA, Santana RF, Broca PV. Capacidade de execução das atividades instrumentais de vida diária em idosos: etnoenfermagem. Esc Anna Nery. 2016;20(3):e20160064. https://doi.org/10.5935/1414-8145.20160064

3. Tomás MT, Galán-Mercant A, Carnero EA, Fernandes B. Functional capacity and level of physical activity in aging: a 3 years follow up. Front Med. 2017;4:244-51. https://dx.doi.org/10.338902Ffmed.2017.00244

4. Prefeitura de Porto Alegre. Plano municipal da pessoa idosa de Porto Alegre: 2016 a 2018. Porto Alegre: Prefeitura de Porto Alegre; 2016. 58 p.

5. rasil. Ministério da Saúde. Portal Ministério da Saúde. Estudo aponta que $79 \%$ dos idosos usam apenas o SUS [Internet]. Brasília: Ministério da Saúde; 2018 [acessado em 17 nov. 2019]. Disponível em: <http:// portalms.saude.gov.br/noticias/agencia-saude/44451-estudo-apontaque-75-dos-idosos-usam-apenas-o-sus>

6. Minosso JSM, Amendola F, Alvarenga MRM, Oliveira MAC. Validação, no Brasil, do Índice de Barthel em idosos atendidos em ambulatórios. Acta Paul Enferm. 2010;23(2):218-23. https://doi.org/10.1590/S0103-21002010000200011

7. Azeredo Z, Matos E. Grau de dependência em doentes que sofreram AVC. Rev Fac Med Lisboa. 2003;8(4):199-204.

8. Bertolucci PH, Bruscki SM, Campacci SR, Juliano Y. The Mini-Mental State Examination in a general population: impact of educational status. Arq Neuropsiquiatr. 1994;52(1):1-7. https://doi.org/10.1590/ S0004-282X1994000100001

9. Lubben J. Assessing social networks among elderly populations. Fam Community Health. 1988;11(3):42-52.

10. Almeida OP, Almeida SA. Confiabilidade da versão brasileira da escala de depressão em geriatria (GDS) versão reduzida. Arq NeuroPsiquiatr. 1999;57(2B):421-6. https://doi.org/10.1590/ S0004-282X1999000300013

11. Kaiser MJ, Bauer JM, Ramsch C, Uter W, Guigoz Y, Cederholm T, et al. Validation of the Mini Nutritional Assessment short-form (MNA-SF): A practical tool for identification of nutritional status. J Nutr Health Aging. 2009;13(9):782-8. https://doi.org/10.1007/s12603-009-0214-7

12. Chumlea WC, Guo SS, Steinbaugh ML. Prediction of stature from knee height for black and white adults and children with application to mobility impaired or handicapped persons. J Am Diet Assoc. 1994;94(12):1385-91. https://doi.org/10.1016/0002-8223(94)92540-2

13. Rokach L, Maimon O. Data mining with decision trees: theory and applications. 2a ed. Tel-Aviv: World Scientific Publishing Co.; 2014.

14. Brito TA, Fernandes MH, Coqueiro RS, Jesus CS, Freitas R. Capacidade funcional e fatores associados em idosos longevos residentes em comunidade: estudo populacional no Nordeste do Brasil. Fisioter Pesq. 2014;21(4):308-13. https://doi.org/10.590/1809-2950/11556021042014

15. Silva SPZ, Marin MJS, Rodrigues MR. Condições de vida e de saúde de idosos acima de 80 anos. Rev Gaúcha Enferm. 2015;36(3):42-8. https://doi.org/10.1590/1983-1447.2015.03.50263

16. Porciúncula RCR, Carvalho EF, Barreto KML, Leite VMM. Perfil socioepidemiológico e autonomia de longevos em Recife-PE, Nordeste do Brasil. Rev Bras Geriatr Gerontol. 2014;17(2):315-25. https://doi. org/10.1590/S1809-98232014000200009

17. Chaimowicz F, editor. Saúde do Idoso. $2^{\mathrm{a}}$ ed. Belo Horizonte: NESCON/ UFMG; 2013. 167 p.

18. Pinto AH, Lange C, Pastore CA, Llano PMP, Castro DP, Santos F. Capacidade funcional para atividades da vida diária de idosos da Estratégia de Saúde da Família da zona rural. Ciênc Saúde Coletiva. 2016;21(11):3545-55. https://doi.org/10.1590/1413-812320152111.22182015

19. Andrade EIG, Chechiglia ML, Souza Junior PRB, Andrade FB, Mambrini JVM, Lima-Costa MF. Factors associated with the receipt of pensions among older adults: ELSI-Brazil. Rev Saúde Pública. 2018;52(Supl. 2):15s. https://doi.org/10.11606/s1518-8787.2018052000665

20. Nascimento CM, Mambrini JVM, Oliveira CM, Giacomin KC, Peixoto SV. Diabetes, hypertension and mobility among Brazilian older adults: findings from Brazilian national household sample survey $(1998,2003$ and 2008). BMC Public Health. 2015;15:591. https://doi.org/10.1186/ s12889-015-1956-2

21. Ribeiro DKMN, Lenardt MH, Michel T, Setoguchhi LS, Grden CRB, Oliveira ESO. Fatores contributivos para a independência funcional de idosos longevos. Rev Esc Enferm USP. 2015;49(1):89-95. https:// doi.org/10.1590/S0080-623420150000100012

22. Carbonell ALI. Estudo da capacidade funcional de idosos com neoplasias mieloides e leucemias agudas: estudo transversal e observacional [tese]. São Paulo: Escola Paulista de Medicina, Universidade Federal de São Paulo; 2013.

23. Sousa KT, Mesquita LAS, Pereira LA, Azevedo CM. Baixo peso e dependência funcional em idosos institucionalizados de Uberlândia (MG), Brasil. Ciênc Saúde Coletiva. 2014;19(8):3513-20. https://doi. org/10.1590/1413-81232014198.21472013

24. Bryła M, Burzyńska M, Maniecka-Bryła I. Self-rated quality of life of city-dwelling elderly people benefitting from social help: results of a cross-sectional study. Health Qual Life Outcomes. 2013;11:181-92. https://doi.org/10.1186/1477-7525-11-181

25. Reis LA, Trad LAB. Percepção de idosos com comprometimento da capacidade funcional acerca do suporte familiar. Kairós Gerontol. 2016;19(22):175-89. https://doi.org/10.23925/2176901X.2016v19iEspecial22p175-189

26. Boulos C, Salameh P, Barberger-Gateau P. Social isolation and risk for malnutrition among older people. Geriatr Gerontol Int. 2017;17(2):28694. https://doi.org/10.1111/ggi.12711

27. Josefsson K, Andersson M, Erikstedt A. Older adults' self-rated health and diferences by age and gnder: a quantitative study. Healthy Aging Res. 2016;5(1):1-10. https://doi.org/10.12715/har.2016.5.1

28. Camarano AA, Kanso S, Leitão e Mello J. Como Vive o Idoso Brasileiro? In: Camarano AA, editor. Os Novos Idosos Brasileiros: muito além dos 60? Rio de Janeiro: IPEA; 2004

29. Oliveira MR. As relações intergeracionais e a participação dos avós na família dos filhos [tese]. Brasília: Universidade de Brasília; 2011.

30. Stoffel LMB. Avaliação do estado nutricional e fatores associados em idosos do Sul do Brasil [dissertação]. Passo Fundo: Universidade de Passo Fundo; 2017 